\title{
Factors Affecting Vegetable Producers Market Outlet Choice in Case of Habru District, North Wollo Zone, Ethiopia
}

\author{
Ebrahim Endris ${ }^{1}$, , Jema Haji², Bosena Tegegne ${ }^{2}$ \\ ${ }^{1}$ Department of Agricultural Economics, Woldia University, Woldia, Ethiopia \\ ${ }^{2}$ School of Agricultural Economics and Agribusiness, Haramaya University, Haramaya, Ethiopia \\ Email address: \\ ebrahime3238@gmail.com (E. Endris),jemmahaji@gmail.com(J. Haji), bosenat@gmail.com (B. Tegegne) \\ ${ }^{*}$ Corresponding author
}

To cite this article:

Ebrahim Endris, Jema Haji, Bosena Tegegne. Factors Affecting Vegetable Producers Market Outlet Choice in Case of Habru District, North Wollo Zone, Ethiopia. European Business \& Management. Vol. 6, No. 1, 2020, pp. 1-9. doi: 10.11648/j.ebm.20200601.11

Received: February 9, 2020; Accepted: February 24, 2020; Published: April 14, 2020

\begin{abstract}
In Ethiopia, horticultural crops play a significant role in improving household income and nutrition status of producers. However, the choice of appropriate market outlets that enhance the benefit of producers is a key challenge facing vegetable producers in Habru district, North Wollo zone, Ethiopia. Hence, this study carried out to identify factors affecting market outlet choice of vegetable producers in Habru district. Both primary and secondary data were used for the study. A random sample of 147 vegetable producer households were selected using a proportional sampling technique. Both descriptive and multivariate probit methods were used for data analysis. Multivariate probit model result showed that age, education level, sex, farming experience, land cultivated, quantity produced, selling price, and extension contact significantly affected onion producers market outlet choice. While education level, sex, farming experience, quantity produced, selling price, extension contact, and non/off-farm income significantly affected tomato producers market outlet choice. The study recommends the need to promote farmer organization for collective marketing and financial support for marketing, boost vegetable production, support market-oriented extension delivery, enhance farmers training and experience exchange of vegetable producers.
\end{abstract}

Keywords: Habru District, Market Outlet, Multivariate Probit, Vegetables

\section{Introduction}

In Ethiopia, horticulture crops play a significant role in improving income and nutrition status of the country [1]. Amhara region has different agroecology and fertile soil that are suitable for producing various types of fruits and vegetables. The region has ideal opportunities for horticultural industry development including abundant surface and groundwater potentials, cheap labor force and increasing demand for horticultural produces both within the domestic and international markets [2].

In 2016/17 Meher season, about 468, 689.1 hectares of land is under vegetable and root crops with a total production of 54.4 million Qt in Ethiopia. The production of vegetables contributes $1.69 \%$ of the entire area under all crops at the national level and $2.17 \%$ of the production of the total crops. The country's onion meher production were $3,274,752.45 \mathrm{Qt}$ and tomato accounting 283,648.27Qt during the year [3]. Habru district where this study conducted is one of naturally endowed areas for vegetable production due to its favorable agroecology and availability of irrigation water. It is mainly for commercial vegetable production in two rounds per year. In 2016/17 production year, about 7, 295 hectares cultivated for vegetables and $872,500 \mathrm{Qt}$ of vegetables produced in the district [4].

Vegetable production in Ethiopia is increasing due to increased area allocation as well as increased yield per unit area. However, vegetable marketing is constrained by lack of market information, poor market linkages, low institutional support, lack of value chain development to ensure participation and benefit to the smallholders [5]. The horticulture industry in Amhara region complicated by the multiplicity of actors, imperfect competition, lack of market information, seasonal price fluctuation, unavailability of 
market facilities and infrastructure, poor handling and transportation are the major marketing constraints [2].

Habru district has irrigation bases for producing a range of vegetables for home consumption and market. Despite this production potential and being a source of income for a large proportion of rural households within the district, vegetable marketing faces various challenges. The perishable nature of product, low price and intermediary malpractices, price volatility, and absence of market linkage altogether impede the potential gains that could be attained from the prevailing opportunities in the district [6]. Even though, Mengesha conducted a study on marketing system analysis of vegetables and fruits in North Wollo zone, the author failed to analyze vegetable producer's market outlet choice in the study area [7]. Therefore, this study aimed to fill the existing research and knowledge gaps by identifying affecting vegetable producers' market outlet choice in Habru district.

\section{Research Methodology}

\subsection{Description of the Study Area}

The study was conducted in Habru district, which is located in North Wollo Administrative zone, Amhara National Regional State of Ethiopia. The district is bordered

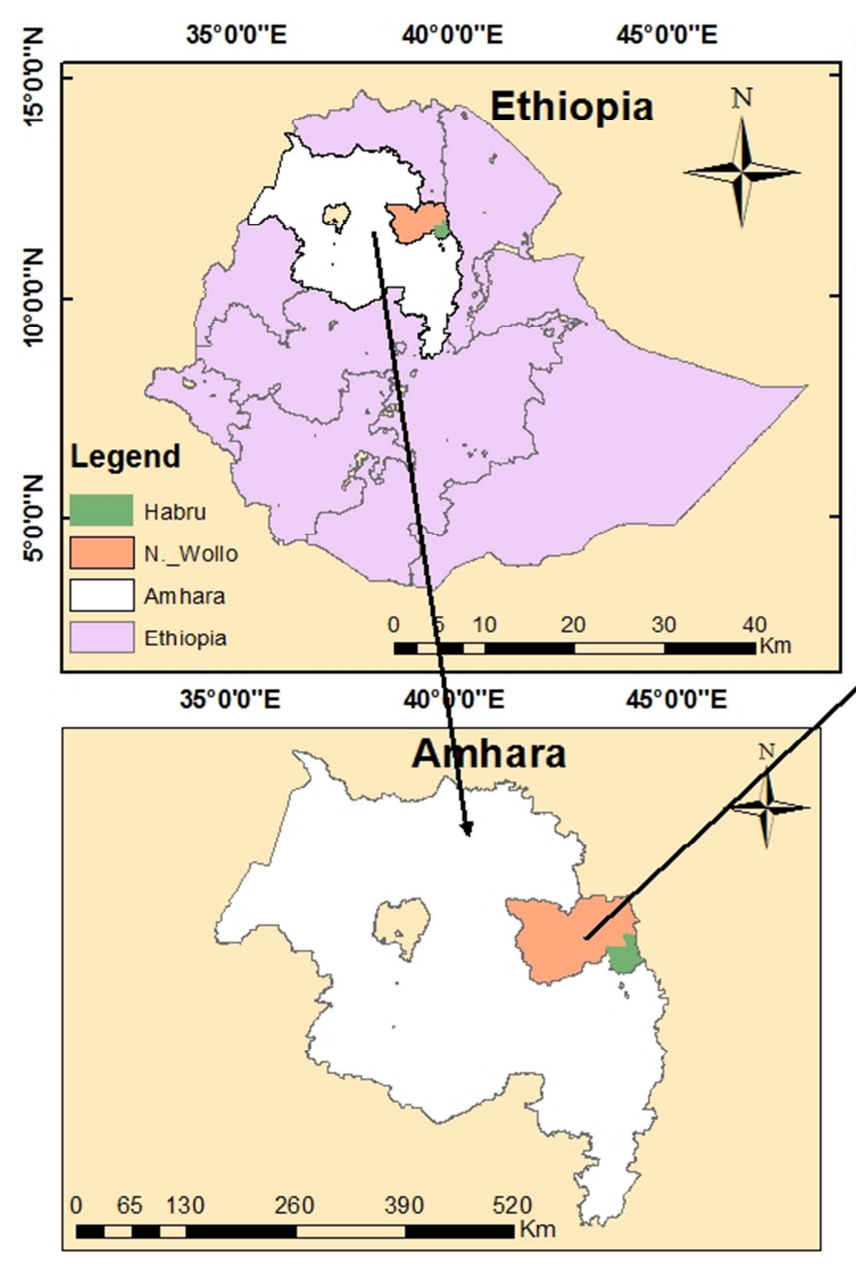

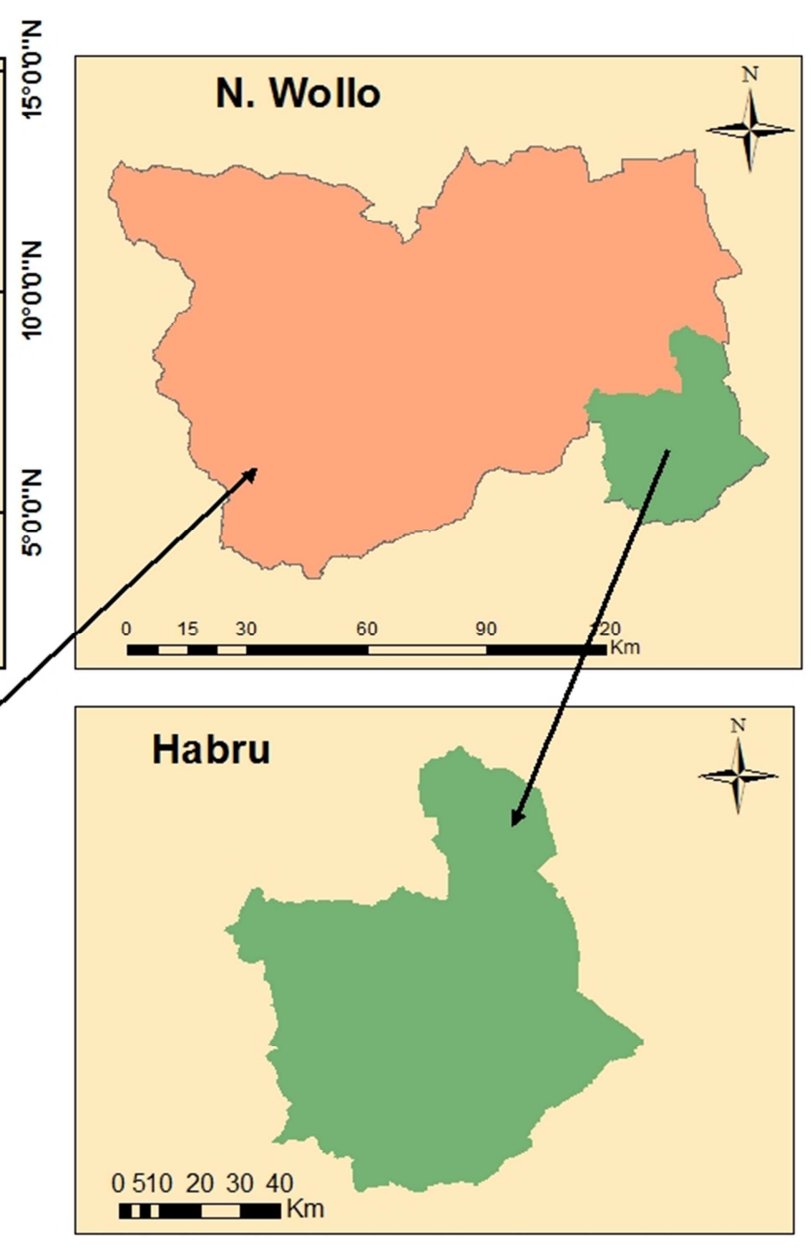

in the south by the Mille River, which separates North Wollo from the South Wollo zone, on the west by Gubalafto Woreda, on the north by the Alawuha river, which separates Habru from Kobo Woreda and on the east by the Afar region. The district has 36 rural kebeles and three sub-urban kebele administrations, with a total area of $1,239.79 \mathrm{~km}^{2}(1,23979$ ha). The town Mersa is the center of the district, which is 491 $\mathrm{km}$ Northeast of Addis Ababa and $30 \mathrm{~km}$ south of Woldia, capital of North Wollo zone [6]. The projected population of the district in $2016 / 17$ is 235,347 , of whom 118,088 are men, 117,259 women and projected urban residence of 37,659 [8]. The mean annual maximum and minimum temperatures of the district is $28.5^{\circ} \mathrm{C}$ and $15^{\circ} \mathrm{C}$, respectively. The pattern of rainfall is erratic with an annual average of $300 \mathrm{~mm}$ but sometimes it ranges from 600-1200 mm [9]. The dominant crops produced in the district are sorghum, barley, wheat, and maize, which are the main food crops produced by the majority of the farmers under rain-fed farming. Besides, fruit and vegetable crops are often produced through irrigation which has boosted the production of onion and tomato in the district. Major types of vegetable crops grown in the district include onion, tomato, cabbage, watermelon, beetroot, and some leafy vegetables [6].

Source: GIS map (2017).

Figure 1. Geographical location map of Habru district. 


\subsection{Types, Sources, and Methods of Data Collection}

In this study, both qualitative and quantitative crosssectional data were collected from primary and secondary sources. Primary data were collected from sample vegetable producers using semi-structured questionnaire in 2017/18 production season. Secondary data were collected from different published and unpublished reports, and bulletins.

\subsection{Sampling Procedure and Sample Size}

Multi-stage sampling method used to select vegetable producing kebeles and sample farm households. In the first stage, from 36 rural kebeles in the district 10 major vegetables (onion and/or tomato) producing kebeles were purposively selected. In the second stage, four kebeles were selected randomly from 10 onion and/or tomato producing kebeles. Finally, from the randomly selected four kebeles, 147 sample households were selected randomly based on proportional to the population size using Yamane formula [10].

Accordingly, out of 2,312 onion and/or tomato producers in randomly selected kebeles of the district 147 sample producers selected using a simple random sampling method at $95 \%$ confidence level with degree of variability of $5 \%$ and level of precision equal to $8 \%$.

Table 1. Sample kebeles and vegetables (onion and/or tomato) producers.

\begin{tabular}{lll}
\hline Sample kebeles & $\begin{array}{l}\text { Number of potato } \\
\text { producer households }\end{array}$ & $\begin{array}{l}\text { Number of sample } \\
\text { households }\end{array}$ \\
\hline Girana & 960 & 61 \\
Gorarba & 750 & 48 \\
Woldia-kurkura & 292 & 18 \\
Libso & 310 & 20 \\
Total & 2312 & 147 \\
\hline
\end{tabular}

Source: Agricultural offices of Habru Woreda and own design (2017).

\subsection{Methods of Data Analysis}

Econometric analysis used to estimate the causal relationship between the dependent variable and the explanatory variables. Multivariate probit model used to identify factors affecting producers' market outlet choice.

\subsubsection{Factors Affecting Market Outlet Choice of Onion and Tomato Producers}

The individual chooses between more than two choices, making the choice that provides the greatest utility. Multivariate probit model a natural extension of the probit model would be to allow more than one equation, with correlated disturbances. The observed outcome of market outlet choice can be modeled following random utility for individual choice [11]. Consider the $\mathrm{i}^{\text {th }}$ farm household ( $\mathrm{i}=1$, $2 \ldots \ldots \mathrm{N}$ ), facing a decision problem on whether or not to choose available market outlets. Let $\mathrm{U}_{0}$ represent the utility farmer get by choosing wholesalers, and $U_{k}$ represents the utility of farmer by choosing the $\mathrm{K}^{\text {th }}$ market outlet; where $\mathrm{K}$ denotes a choice of any alternative outlet. The observed choice between the two reveals which one provides the greater utility. Hence the farmer decides to choose the $\mathrm{K}^{\text {th }}$ market outlet if $U_{k}>U_{o}$.

The net benefit latent regression model can be specified as:

$$
Y_{i k}{ }^{*}=X_{i}{ }^{\prime} \beta_{k}+\varepsilon_{i}
$$

Where

$Y_{i k}{ }^{*}$ Unobserved variable representing the latent utility of choosing outlet $\mathrm{k}$.

$X_{i}$ vector of observed characteristics determining the choice of market outlet.

$\beta$ represents a vector of unknown coefficients to be estimated, and

$\varepsilon$ represents a vector of error terms.

The net benefit $Y_{i k}{ }^{*}$ that the farmer derives from choosing a market outlet is a latent variable determined by observed explanatory variables $(\mathrm{X})$ and the error term $(\varepsilon)$ :

$$
Y_{i k}=\left\{\begin{array}{l}
1 \text { if } Y_{i k}^{*}>0 \\
0 \text { othewise }
\end{array}\right.
$$

Yik* is an unobservable latent variable denoting the probability of choosing $\mathrm{k}$ type of market outlet by an individual, for $\mathrm{k}=1$ (Collectors), $\mathrm{k}=2$ (Retailers), $\mathrm{k}=3$ (Wholesalers) $\mathrm{k}=4$ (Consumers). The model specified as follows:

$$
\begin{aligned}
\mathrm{Y}_{i 1}{ }^{*} & =\beta_{1} X_{i}{ }^{\prime}+\varepsilon_{i 1} \\
\mathrm{Y}_{i 2}{ }^{*} & =\beta_{2} X_{i}{ }^{\prime}+\varepsilon_{i 2} \\
\mathrm{Y}_{i 3}{ }^{*} & =\beta_{3} X_{i}{ }^{\prime}+\varepsilon_{i 3} \\
\mathrm{Y}_{i 4}{ }^{*} & =\beta_{4} X_{i}{ }^{\prime}+\varepsilon_{i 4}
\end{aligned}
$$

Where, $Y_{i 1}=1$, if farmer choose collectors ( 0 otherwise), $Y_{i 2}=1$, if farmer choose retailers ( 0 otherwise), $Y_{i 3}=1$, if farmer choose wholesalers ( 0 otherwise), $Y_{i 4}=1$, if farmer choose consumers ( 0 otherwise), $X_{i}=$ vector of factors affecting market outlet choice, $\beta=$ vector of unknoun parameters and $\varepsilon_{i}=$ is the error term.

\subsubsection{Definition of Variables and Working Hypothesis Dependent Variables}

Market outlets (mktout): A dummy variable that represents the market outlet preference of the farmer to sell his/her onion or tomato produce to different markets outlets. Each outlet is binary dependent variables modeled as 1 for those households who choose to sell and 0 otherwise.

\section{Independent Variables}

Age of the household head (age): It is a continuous variable measured in years. Feyissa finding showed that age of the household head negatively affects the likelihood of choosing retailer outlet [12]. Aged households are believed to be wise in searching better price offering market outlet, whereas young household heads are active in obtaining information which enables them to choose the right outlet. Therefore, this variable was hypothesized either positively or negatively influence wholesaler outlet choice.

Family size (famsz): This is a continuous variable, which 
refers to the total number of family members in the household measured in man equivalent. The availability of active labor force in a household is assumed to affect farmers' decisions in choosing a better market outlet. Family size positively affects the choice of wholesaler outlet [13]. Therefore, family size was hypothesized to influence wholesalers and retailers' outlet choice positively.

Distance to the nearest market (dstmkt): It is a continuous variable that is measured in kilometers that producers are required to travel to sell their product to the nearest market. Distance from the nearest market is negatively associated with the likelihood of farmers selling potato to retailers [14]. This reflects that producers prefer to sell nearby their farm rather than transporting the product to retailers in the market. Therefore, the variable was hypothesized to be negatively related with the likelihood of selling wholesaler and retailer market outlet choice.

Farming experience (exper): Vegetable farming experience is a continuous independent variable measured in the number of years a household has been engaged in vegetable production and marketing. The likelihood of choosing collectors and wholesalers channels negatively and positively affected by farming experience respectively [14]. Therefore, farming experience was expected to have a positive relationship in choosing wholesalers outlet than other market outlets.

Sex of the household head (sex): A dummy variable that takes a value of one if the household head is male and zero otherwise. Addisu showed that gender positively and significantly associated with the choice of collector outlet [15]. Therefore, sex of the household heads was expected to have a positive influence in choosing wholesalers and collectors outlet choice.

Selling price (price): This is a continuous variable measured in birr per quintal. It represents the average price of onion or tomato a farmer receives from selling his/her produce in 2016/17. Selling price influence producer's outlet choice as better price offer provides an incentive for farmers to choose particular market outlets. Therefore, selling price was expected to influence higher outlet choices of producers positively.

Quantity produced (Qtprod): It is a continuous variable measured in quintals per year and expected to influence market supply positively. Farmers producing small quantities are likely to sell their produce to the retail market outlet than selling to wholesaler outlet who purchase bulk quantity. The quantity of mango produced determined the choice of wholesaler market outlet positively [13]. It was expected to influence wholesaler market outlet choice positively.

Frequency of extension contacts (extcon): It is a continuous variable, which refers to the frequency of contacts that producers have with an extension agents per month. Extension contact enables producers to get information on the choice of market outlets that offer a higher price. Access to extension service positively and significantly affected accessing wholesalers' market outlet choice [16]. Therefore, this variable was hypothesized to influence the choice of wholesaler outlet positively; collector and retailer outlet negatively.

Education level of household head (edu): It is a continuous variable measured in years of formal schooling of the household head attended. Education increases farmer's ability to get and use information and estimate the cost and benefit of searching for a higher price. Chala and Chalchisa finding showed that educational status decreases the probability of choosing retailer outlet for vegetable marketing and increases the choose of wholesaler market outlet [17]. Therefore, this variable was hypothesized to influence consumer and retailer outlet choice negatively.

Land cultivated for vegetable (lancult): It is a continuous variable that refers to the total area of land cultivated for vegetable production in hectare. Vegetable land size negatively influence the choice of collector outlet and positively affects the choice of farmers' cooperative [18]. Hence, area allocated for onion / tomato was hypothesized to influence positively on the choice of wholesaler market outlet.

Non/off-farm income (noffarm): It is a dummy variable measured in terms of whether the household obtained income from off and non-farming activities. It is 1 if the household is involved in non/off farm activities and 0 otherwise. Addisu showed that off/non-farm income negatively affects retailer outlet choice of onion producers [15]. Therefore, this variable was hypothesized to influence retailer outlet choice negatively.

\section{Results and Discussion}

From a total of 147 sample households, the number of households producing both onion and tomato was 95 and the remaining 32 households produce only onion while 20 households produce only tomato in the survey year. The total number of sample onion producers were 127 and the number of sample tomato producers were 115 households.

The econometric analysis used to investigate factors affecting onion and tomato market outlet choice of producers. The analysis was conducted for onion and tomato independently. Vegetable (onion and tomato) producers in the study area have four major market alternatives to sell their products. Multivariate probit model estimated jointly for four binary dependent variables namely wholesalers, collectors, retailers, and consumers market outlet.

\subsection{Factors Affecting Onion Producers Market Outlet Choice}

The number of respondents who choose collectors, retailers, wholesalers and consumers outlet were 81, 42, 64 and 52 onion producers, respectively. The Wald test $\left(X^{2}(44)=124.70, \mathrm{p}=0.0000\right)$ is significant at $1 \%$ significance level, which implies that the coefficients are jointly significant and the explanatory power of the factors included in the model is satisfactory. The likelihood ratio test of the null hypothesis of independency between market outlet choice decision $(\mathrm{rho} 21=\mathrm{rho} 1=\mathrm{rho} 41=\mathrm{rho} 32=\mathrm{rho} 42=\mathrm{rho} 43=0)$ is rejected at 
$1 \%$ significant level and there are significant joint correlations for two estimated coefficients across the equations in the model.

There is significant negative correction between wholesalers and collectors, collectors and retailer onion market outlets. The negative correlation indicating a competitive relationship that onion producers use collector outlet as a substitute for wholesaler outlet in Habru district. The simulation results also indicate that the probability that onion producers choose collectors, retailers, wholesalers, and consumers market outlet were $63.27 \%, 33.85 \%, 52.95 \%$, and $41.96 \%$, respectively. The joint probability of choosing all market outlets was $1.26 \%$ and the joint probability of failure to choose all market outlets was $0.54 \%$.

Age of household head (age): Older household heads are more likely to sell onion produce to collector outlet than other market alternatives. The positive effect of household head age on the choice of collector outlet indicates that as the household head gets older may be the labor-intensive nature of onion marketing becomes more difficult to transport their produce to the market and they prefer to sell to collectors nearby their farm.

Education (edu): The likelihood of choosing wholesaler and consumes market outlet was positively and negatively affected by education level of household heads respectively at $1 \%$ significance level. This is because educated farmers are expected to have better access to information and ability to process information, which increases the awareness of producers about the benefits of choosing a profitable market outlet. The result compromise with Addisu who found that educated farmer less likely to sell potato through consumer outlet because educated farmers value their time devoted to marketing activities [15].

Sex of household head (sex): Being male-headed households increase the likelihood of selling onion to collectors and decreases the likelihood of selling to the consumer outlet as compared to female-headed households. The result indicated that female-headed households are more likely to sell to consumers outlet than male counterparts. This suggests that male household heads are believed to be busy in fieldwork hence sell their produce to collector nearby their farm. Addisu confirmed that male-headed producers are more likely to deliver potato to collector outlet than female-headed households [15]. Furthermore, female household heads are less likely to sell vegetable to a collector outlet [18].

Table 2. Multivariate probit estimation results for determinants of onion market outlet choice.

\begin{tabular}{|c|c|c|c|c|}
\hline \multirow{2}{*}{ Variable } & Collectors & \multirow{2}{*}{$\begin{array}{l}\text { Retailers } \\
\text { Coef. (Std. Err.) }\end{array}$} & \multirow{2}{*}{$\begin{array}{l}\text { Wholesalers } \\
\text { Coef. (Std. Err.) }\end{array}$} & \multirow{2}{*}{$\begin{array}{l}\text { Consumers } \\
\text { Coef. (Std. Err.) }\end{array}$} \\
\hline & Coef. (Std. Err.) & & & \\
\hline age & $0.04 *(0.022)$ & $-0.02(0.017)$ & $0.002(0.016)$ & $-0.02(0.017)$ \\
\hline edu & $-0.16(0.13)$ & $-0.09(0.099)$ & $0.33^{* * *}(0.098)$ & $-0.32 * * *(0.104)$ \\
\hline $\operatorname{sex}$ & $1.10 * *(0.433)$ & $-0.13(0.32)$ & $0.18(0.356)$ & $-0.78 * *(0.339)$ \\
\hline famsz & $-0.28(0.683)$ & $0.43(0.541)$ & $0.67(0.577)$ & $0.35(0.525)$ \\
\hline Exper & $-0.11(0.073)$ & $-0.1 *(0.058)$ & $0.15^{* *}(0.058)$ & $0.04(0.058)$ \\
\hline Lancult & $2.92(2.955)$ & $0.53(2.221)$ & $-0.75(2.435)$ & $-4.91 * *(2.272)$ \\
\hline Qtprod & $-0.05(0.051)$ & $-0.03(0.038)$ & $0.1 * *(0.039)$ & $0.04(0.037)$ \\
\hline Price & $-0.02 * * *(0.005)$ & $-0.0002(0.003)$ & $0.007 *(0.004)$ & $0.006(0.004)$ \\
\hline dstmkt & $0.04(0.031)$ & $-0.004(0.024)$ & $-0.03(0.025)$ & $-0.01(0.023)$ \\
\hline extcon & $-0.28 *(0.15)$ & $-0.09(0.115)$ & $0.33 * *(0.129)$ & $-0.02(0.113)$ \\
\hline noffarm & $-0.42(0.328)$ & $-0.19(0.259)$ & $0.26(0.273)$ & $-0.23(0.263)$ \\
\hline Constant & $15.46 * * *(3.974)$ & $1.97(2.919)$ & $-12.82^{* * *}(3.409)$ & $-3.3(3.078)$ \\
\hline Predicted probability & 0.6327 & 0.3385 & 0.5295 & 0.4196 \\
\hline Joint probability (succ & & & 0.0126 & \\
\hline Joint probability (fail & & & 0.0054 & \\
\hline Number of observatio & & & 127 & \\
\hline Number of draws (\#): & & & Log likelihood $=-226.01$ & \\
\hline \multicolumn{5}{|c|}{ Wald chi2 $(48)=124.70^{* * *}$} \\
\hline \multicolumn{5}{|c|}{ Estimated correlation matrix } \\
\hline & $\rho_{1}$ & $\rho_{2}$ & $\rho_{3}$ & $\rho_{4}$ \\
\hline$\rho_{1}$ & 1.00 & & & \\
\hline$\rho_{2}$ & $-0.232 *(0.130)$ & 1.00 & & \\
\hline$\rho_{3}$ & $-0.734 * * *(0.084)$ & $0.005(0.145)$ & 1.00 & \\
\hline$\rho_{4}$ & $-0.06(0.129)$ & $0.134(0.12)$ & $-0.18(0.127)$ & 1.00 \\
\hline \multicolumn{5}{|c|}{$\begin{array}{l}\text { Likelihood ratio test of rho21=rho31=rho41=rho32=rho } 42=\text { rho } 43=0 \text { : } \\
\text { chi2 }(6)=37.8102^{* * *}\end{array}$} \\
\hline
\end{tabular}

Note: Dependent variable is onion market outlet choice where $\mathrm{Y} 1=$ Collectors, $\mathrm{Y} 2=$ Retailers, $\mathrm{Y} 3=$ Wholesalers and $\mathrm{Y} 4=$ Consumers.

$*, * *$ and $* * *$ indicate statistical significance at 10,5 and $1 \%$, respectively.

Source: survey result (2017). 
Farming experience (exper): It has a positive relationship with the likelihood of choosing wholesalers market outlet and negatively related to the choice of retailer outlet. The result showed that households with many years of engagement in onion farming are more likely to choose wholesalers and less likely to choose retailers outlet. This may be due to experienced farmers have better knowledge of analyzing cost and benefits associated with various marketing outlets that give enable producers to choose outlets increase sales volume and profit. Experienced households in potato production more likely to deliver potato to wholesaler outlet [15].

Land cultivated to onion (lancult): land cultivated to onion has a negative and significant effect on households' choice of consumer market outlet. This implies that households with a large area of cultivated onion probably produce large volume of onion and less likely to sell to consumer outlet who buy in small quantity. The result supported by Mebrat who found that farm size negatively affected the probability of farmers' choice of retailer outlet as farmers with larger total landholding produce large amount and prefer to sell to wholesalers in bulk quantities [19].

Quantity of onion produced (Qtprod): It affected the likelihood of choosing wholesalers market outlet positively. The result indicated that those households with a larger quantity of onion produced prefer wholesaler market outlet. This might be due to wholesalers pay fair price and buy in bulk to make proper profit margin and large sales. Large volume of sale motivates households to prioritize the channels and decide to use the best alternative [18].

Selling price (price): Selling price of onion positively affected wholesalers' market outlet choice whereas it negatively affected collectors outlet choice. This might be due to wholesalers offer a higher price to producers relative to collector outlet, which constrain farmers to choose collectors outlet. The result of the study concedes with Fikiru et al. who found market price of sesame has positive effect on wholesalers' market outlet choice and negative effect on collector outlet choice of farmers [20].

Frequency of extension contact (extcon): It has a positive and negative influence on wholesalers and collector outlet choice respectively. Frequent extension contact expected to increase the ability of farmers to acquire essential market information as well as other related agricultural information, which in turn increases farmer's ability to choose the best market outlet for their product. The result is in line with Abraham who found access to extension service negatively and significantly associated with use of collectors and retailer outlet relative to using wholesaler outlet [21].

\subsection{Factors Affecting Tomato Producers Market Outlet Choice}

The bulk quantity of tomato supplied to wholesalers and collector outlet, which accounted for $46.6 \%$ and $40.8 \%$ of sample respondents tomato supply respectively. The number of respondents who choose collectors, retailers, wholesalers and consumers outlet were $63,39,61$ and 25 tomato producers, respectively. The Wald test $\left(X^{2}(44)=95.18\right.$, $\mathrm{p}=0.0000)$ is significant at $1 \%$ significance level, which implies that the coefficients are jointly significant and the explanatory power of the factors included in the model are satisfactory. The likelihood ratio test of the null hypothesis of independency between market outlet choice decision $($ rho2 $1=$ rho3 $1=$ rho41 $=$ rho32 $=$ rho $42=$ rho43 $=0)$ is rejected at $1 \%$ significant level and there are significant joint correlations for two estimated coefficients across the equations in the model. The likelihood ratio test for correlation between outlets showed that there is negative and significant interdependence between wholesaler and collector outlet. The result showed that the likelihood of households to choose collectors, retailers, wholesalers and consumers outlet were $55.35 \%, 33.99 \%, 54.12 \%$, and $22.88 \%$ respectively. It also showed that the joint probability of choosing all market outlets was $0.44 \%$ and the joint probability of failure to choose all market outlets was $0.97 \%$.

Education (edu): Education level of household head positively affected the likelihood of choosing wholesalers outlet and it negatively affected the choice of collectors, retailers and consumers outlets. Education increases the ability of farmers to analyze relevant market information and choose the best market outlet that expected to give a better price for their produce. This finding is consistent with Chala and Chalchisa who found that education decreases the probability to choose retailers outlet and increases the likelihood of choosing wholesaler outlet for vegetable marketing [17]. Moreover, education level of household head negatively related to retailer outlet [21].

Sex of household head (sex): Sex of household head affected the likelihood of choosing retailer outlet positively and consumers outlet negatively at $5 \%$ and $1 \%$ significance level respectively. The result implies that being male households headed increases the likelihood of choosing retailers outlet and decreases the likelihood of choosing consumers outlet. This may be due to the reason that males may be busy in farm tasks more than female-headed households and they may deliver to retailers in bulk, which lower transaction time to return to their farm activity. Female household heads are believed to have less participation in farm activities choice consumers outlet that enables producers to grasp the total market margin through directly supply of the product to ultimate consumers.

Farming experience (exper): The likelihood of choosing collector and wholesaler outlet was negatively and positively affected by tomato farming experience respectively. The result shows that households with many years of vegetable farming experience more likely to choose wholesaler outlet than other market outlet alternatives. This is due to the fact that experienced households expected to have market information and linkage with wholesalers who buy bulk quantity at better price. The finding confirmed by Bezabih et al. who found that the likelihood of choosing potato collectors and wholesalers outlet negatively and positively affected by farming experience respectively [14]. 


\section{Conclusion and Recommendations}

\subsection{Conclusion}

Fruit and vegetables are source of income for a large proportion of rural households in Habru district. The district naturally endowed for vegetable production mainly onion, tomato, cabbage, watermelon, beetroot and some leafy vegetables due to its favorable agroecology and availability of irrigation water. There are various marketing problems impede the development of the subsector in the district. This study aimed to identify factors affecting vegetables market outlet choice in Habru district. The primary data were collected from 147 vegetable producers using pre-tested semi-structured questionnaires and secondary data from different district offices, CSA, SARC, published and un published reports, and bulletins.

The multivariate probit (MVP) model applied to identify factors affecting onion and tomato producers' market outlet choice. The MVP result of onion outlet choice showed that age and sex of household head positively affected collector outlet while selling price and extension contact negatively affected the choice of collector outlet. The choice of retailer outlet negatively affected by onion farming experience; wholesaler outlet choice positively affected by education level, farming experience, quantity produced, selling price and frequency of extension contact; consumers outlet choice negatively determined by education level, sex of household heads and size of onion cultivated land. The correlations between the onion producers' choice of wholesaler and collector, collector and retailer outlet were negative and significant. This shows that onion producers used collector outlet as a substitute for both retailers and wholesaler outlet in Habru district.

The MVP result of tomato market outlet revealed that education level, tomato farming experience, selling price, frequency of extension contacts and non/off-farm income negatively affected the choice of collector outlet. The choice of retailer outlet choice positively influenced by sex of household heads and negatively by education level; wholesaler outlet choice positively affected by education level, farming experience, quantity produced, selling price and frequency of extension contact. Tomato selling price positively affected the choice of consumer outlet while sex of household heads and education level negatively affected the choice of consumers outlet. The negative correlations between wholesalers and collectors indicates that tomato producers used collector outlet as substitute for wholesaler outlet in Habru district.

\subsection{Recommendations}

Policy recommendations are drawn from the study findings as follows:

1. Government and development intervention should focus on enhancing onion and tomato production, which could be achieved through encouraging the use improved inputs, new technology and techniques that boost farmers production and productivity.
2. Market-oriented extension that enhances marketing skill and knowledge of producers should be considered as an integral part of agricultural extension programme. This includes disseminate relevant market information that connect smallholder producers' to better offering outlet and protect from being exploited by collusive traders.

3. The provision of financial support through strengthening rural microfinance for market transactions and establishment of farmer organizations is needed to support farmers to supply for better offering outlet, thus reduce producers' transaction costs, increases producers' bargaining power and tackle marketing difficulties.

4. The study suggests the need to upgrade farmers' experience and education through frequent capacity building sessions, adult literacy program, continuous training and experience sharing discussion among vegetable producers.

\section{References}

[1] EHPEA (Ethiopia Horticulture Producers and Exporters Association). (2013). Ethiopian Investment Commission database of licensed projects; Embassy of Ethiopia in China; All Africa.

[2] ANRSBoA (Amhara National Regional State Bureau of Agriculture). 2015. Amhara Region Horticulture Development Strategy (2015-2019), Bahir Dar, Ethiopia.

[3] CSA (Central Statistical Agency). (2017). Agricultural sample survey report on Area and production of major Crops (private peasant holdings, meher season 2016 / 2017); Addis Ababa Ethiopia, the FDRE statistical bulletin, Volume I.

[4] OHWARD (Office of Habru Woreda Agriculture and Rural Development). (2017). Annual report of the Woreda. North Wollo Zone, Amhara Regional Sate, Ethiopia.

[5] Bezabih Emana, Amsalu Ayana, Tesfaye Balemi and Milkessa Temesgen. (2014). Scoping study on vegetables seed systems and policy in Ethiopia. Final report, Addis Ababa, Ethiopia.

[6] OHWARD (Office of Habru Woreda Agriculture and Rural Development). (2016). Annual report of the Woreda. North Wollo Zone, Amhara Regional Sate, Ethiopia.

[7] Mengesha Yayo. (2015). Marketing system analysis of vegetables and fruits in Amhara Regional State: Survey evidence from Raya Kobo and Harbu Woredas. Ethiopian Journal of Economics, 24 (2): 1-42.

[8] CSA (Central Statistical Agency). (2013). Population projection of Ethiopia for all regions at district level. Addis Ababa, Ethiopia.

[9] SARC (Sirinka Agriculture Research Center). (2015). Annual report of the research institute, North Wollo Zone, Amhara Regional Sate, Ethiopia.

[10] Yamane, T. (1967). Statistics, an Introductory Analysis, $2^{\text {nd }}$ Edition. New York: Harper and Row.

[11] Greene, W. H. (2012). Econometric Analysis, $7^{\text {th }}$ Edition. Pearson Prentice Hall, USA. 
[12] Feyissa Gobena. (2017). Value chain analysis of ware potato: The case of Tiyo District, Arsi Zone, Oromia National Regional State, Ethiopia. MSc Thesis, Haramaya University, Haramaya, Ethiopia.

[13] Takele Honja, Endrias Geta and Amsalu Mitiku. (2017). Determinants of market outlet choice of the smallholder mango producers: The case of Boloso Bombe Woreda, Wolaita Zone, Southern Ethiopia: A multivariate probit approach. Global Journal of Science Frontier Research, 17 (2): 23-30.

[14] Bezabih Emana, Mengistu Ketema, Mutimba, K. and Jemal Yousuf. (2015). Factors affecting market outlet choice of potato producers in Eastern Hararghe Zone, Ethiopia. Journal of Economics and Sustainable Development, 6 (15): 159-172.

[15] Addisu Hailu. (2016). Value chain analysis of vegetables: The case of Ejere district, West Shoa Zone, Oromia National Regional State of Ethiopia. MSc Thesis, Haramaya University, Haramaya, Ethiopia.

[16] Jafer Ahmed, Abdulaziz Umare, Nasir Mahamed, Oromia Galane and Kebret Desse. (2017). Factors affecting groundnut market outlet choice in moisture stress area of Babile district, Eastern Ethiopia: Multivariate probit approach. International Journal of Agricultural Science, Research and Technology in Extension and Education Systems, 7 (2): 91-101.
[17] Chala Hailu and Chalchisa Fana. (2017). Determinants of market outlet choice for major vegetables crop: Evidence from smallholder farmers of Ambo and Toke-Kutaye districts, West Shewa, Ethiopia. International Journal of Agricultural Marketing, 4 (2): 161-169.

[18] Bessy, K. M., Nongluck, S. and Yaowarat, S. (2014). Factors influencing vegetable farmer's choice of marketing channel in Khon Kaen, Thailand. Khon Kaen Agricultural Journal, 42 (4): 595-604.

[19] Mebrat Tola. (2014). Tomato value chain analysis in the central rift valley: The case of Dugda Woreda, East Shoa Zone, Oromia National Regional State, Ethiopia. MSc Thesis, Haramaya University, Haramaya, Ethiopia.

[20] Fikiru Temesgen, Bezabih Emana, Fikadu Mitiku and Efa Gobana. (2017). Application of multivariate probit on determinants of sesame farmers market outlet choices in Gimbi district, Ethiopia. African Journal of Agricultural Research, 12 (38): 2830-2835.

[21] Abraham Tegegn. (2013). Value chain analysis of vegetables: The case of Habro and Kombolcha Woredas in Oromia Region, Ethiopia. MSc Thesis, Haramaya University, Haramaya, Ethiopia. 